\title{
HIV Incidence Assessment Model, Based on the Incidence of Sexually Transmitted Infections in of Russia
}

\author{
Fishman B*, Tkachenko T, Shevnina U, Azovceva 0, Yuhno M, \\ Moskvin I, Karpov D, Fedchenko P and Rumyantsev Y \\ Institute of Medical Education, Yaroslav-The-Wise Novgorod State University, Russia
}

*Corresponding author: Professor Boris Fishman, Institute of Medical Education, Yaroslav-The-Wise Novgorod State University, Russia, Email: Fishman@mxc.ru

\section{Research Article \\ Volume 2 Issue 10}

Received Date: September 18, 2018

Published Date: September 21, 2018

\begin{abstract}
In Russia, the HIV epidemic continues to grow. Transfer of individuals from vulnerable groups to general population has become more active. While maintaining the current rate of HIV infection and the lack of adequate systemic measures to prevent its spread, the outlook for the development of the situation remains unfavorable. For a while, the issues of HIV and STI were considered independently of each other. In reality, there is an objective relationship between the spread of HIV infection and STIs. The presence in a person of any STI on average 3-4 times or even more increases the risk of contracting HIV. Especially the risk increases with the presence of several STIs simultaneously. The existing malfunctions of the mucous membranes as a result of STI infection are open gates for the immunodeficiency virus. However, research of the possibility of predicting the number of patients with HIV infection, depending on the incidence of STIs is extremely rare. These infections are treated in various institutions, which makes it extremely difficult to develop a unified methodological approach to solving this problem.

Thus, epidemiological surveillance of STIs, as well as control over sexual health, is an integral part of HIV-positive care, since the presence of certain STIs contributes to the further growth of the HIV epidemic.

Keywords: Mathematical Model; HIV infection; Sexually Transmitted Diseases
\end{abstract}

\section{Introduction}

Sexually transmitted infections (STIs) are recognized as one of the most important problems in modern public health and the core aspects of national sexual and reproductive health services [1]. However, according to current publications, works devoted to HIV infection and sexually transmitted diseases are not interconnected and are of a narrow-gauge nature [2-6]. The Global Strategy for the Prevention and Control of STIs, 2006-2015, endorsed by the 59th World Health Assembly, is an integral part of STI prevention, including timely and effective treatment, and should be the main platform for action against HIV infection [5]. To achieve these goals, an accented public health approach is required, based on sound scientific evidence and economic profitability $[1,6]$.

Most fully from the modern analytical point of view, this problem is reflected in the works of Professor SL Plavinsky, and co-authors [7,8]. In general, only the GLOBUS multicentre study (Global Association of Efforts against AIDS) is devoted to the problem in Russia $[3,7]$. The study analyzes the results of a questionnaire survey of 5502 people at risk of HIV infection (injecting drug users and commercial sex workers) conducted in 2006- 


\section{Virology \& Immunology Journal}

2008 in 10 regions of the Russian Federation that were part of the GLOBUS project. The authors show that STIs are a risk factor for HIV infection, increasing its risk by a factor of 1.5-2.0 (the effect is cumulative), and that at the risk group there is a cross-over of the sex networks that transmit STI agents, leading to the emergence of a significant number of cases of infection by combination of pathogens. Analysis of the obtained data included the construction of conjugacy tables, an assessment of the relationship between the indicators using the chi2 and Cochran-Mantel-Haenszel test. Evaluation of the hypothesis of the connectivity of the fact of transferring combinations of various STIs was verified by constructing a log-linear model in accordance with the recommendations. The study of the relationship between STIs and the presence of HIV infection was carried out using logistic regression. The authors obtained convincing data indicating a combination of STIs, with diseases such as syphilis and gonorrhea. Thus, it was shown that for a more detailed answer to the question of the compatibility of different STIs, it was necessary to construct a multidimensional log-linear model. The authors analyzed the relationship between the presence of HIV infection and STIs in patients. To this end, a logistic regression model was constructed in which the dependent variable was the presence or absence of HIV infection, and independent - the presence of STI, the occupation of commercial sex work, the use of injecting drugs during the month prior to the survey and sex. In addition, the model was built with stratification by region, due to the different incidence of HIV infection in the regions included in the study. The analysis showed that the presence of syphilis, gonorrhea and trichomoniasis is associated with a higher incidence of HIV infection (after adjustment for sex, survey region, drug use and sex work). The chances of having HIV infection in people who reported that they had syphilis were 1.8 times higher than those who did not have syphilis (OR $=1.76,95 \% \mathrm{CI}=$ 1.32-2.34), for gonorrhea the growth was 1.5 times (OR = $1.48,95 \% \mathrm{CI}=1.19-1.82$ ) and for trichomoniasis 1.6 times $(95 \%$ CI $=1.19-2.18)$. Chlamydia does not significantly increase the risk of HIV infection. It is important to note that for syphilis and trichomoniasis the effect was additive, i.e. a person infected with syphilis and trichomoniasis had a chance of being infected with HIV, exceeding those in the absence of infection by 2.8 times [9-12].

In general, the authors argue that the risk group studied is a crossroads of various sexual networks, so the presence of one disease increases the possibility of having other infections, and the STI itself is a risk factor for HIV infection.

The data obtained by the authors are not indisputable, since the Odds Ratio is accompanied by low values of the Gaussian density. Obviously, for the completeness of the proof it was necessary to use at least 3 methods of analytical statistics, the result of which should be tau statistics, as the most conservative. However, the obtained data are strategic and allow us to determine the tactics in assessing the interaction of different STIs.

\section{Methods}

Study was conducted using the method of continuous longitudinal/cross-sectional study with coverage of all cases of STI and all cases of HIV infection in the period of 8 years of follow-up. Given the different population density in the region and the presence of the University in the regional center, we conducted a survey among both rural and urban population. Descriptive, parametric/nonparametric and multidimensional analysis (as the most informative) were applied. All 4 infections are selected, as having immunological, clinical and documented (by disease transmission way) data.

\section{Results}

Descriptive analysis using parametric criteria indicates that $\mathrm{M} \pm \mathrm{SD}$ is the highest for trichomoniasis, especially among women. This infection is dominant among all STIs. However, there are no gender differences ( $\mathrm{P}>0.05$, as in the application of the Student's test with Bonferroni correction, and with the F-test). At the same time, when assessing the incidence of trichomoniasis among the population of Veliky Novgorod, the t-test values are statistically significant $(\mathrm{P}<0.001$ and $\mathrm{F}$-test $\mathrm{P}$ $<0.008$ ), indicating a prevalence of morbidity among men.

\begin{tabular}{|c|c|c|c|c|c|c|}
\hline Indicators & M \pm SD & m & “t” & P & F-test & P \\
\hline \multicolumn{7}{|c|}{ Novgorod region } \\
\hline \multicolumn{7}{|c|}{ Men } \\
\hline Clamidiosis & $55.48 \pm 29.29$ & 24.39 & -1.432 & 0.171 & 1.078 & 0.918 \\
\hline Trichomoniasis & $209.84 \pm 75.99$ & 57.48 & -0.661 & 0.518 & 1.139 & 0.858 \\
\hline Genital herpes & $5.96 \pm 3.84$ & 3.15 & -1.836 & 0.085 & 1.309 & 0.712 \\
\hline Anogenital warts & $8.37 \pm 6.18$ & 3.88 & -0.857 & 0.404 & 1.931 & 0.371 \\
\hline
\end{tabular}




\section{Virology \& Immunology Journal}

\begin{tabular}{|c|c|c|c|c|c|c|}
\hline \multicolumn{7}{|c|}{ Women } \\
\hline Clamidiosis & $75.63 \pm 30.41$ & 21.4 & - & - & - & - \\
\hline Trichomoniasis & $232.79 \pm 71.20$ & 57.45 & - & - & - & - \\
\hline Genital herpes & $9.08 \pm 3.35$ & 2.24 & - & - & - & - \\
\hline Anogenital warts & $10.55 \pm 4.45$ & 3.35 & - & - & - & - \\
\hline \multicolumn{7}{|c|}{ Veliky Novgorod } \\
\hline \multicolumn{7}{|c|}{ Men } \\
\hline Clamidiosis & $91.79 \pm 73.30$ & 59.24 & 1.706 & 0.107 & 4.606 & 0.045 \\
\hline Trichomoniasis & $371.84 \pm 118.94$ & 88.66 & $6.154^{*}$ & $0.001^{*}$ & $8.006^{*}$ & $0.008^{*}$ \\
\hline Genital herpes & $8.59 \pm 6.10$ & 3.96 & 0.13 & 0.898 & 1.649 & 0.495 \\
\hline Anogenital warts & $8.26 \pm 4.75$ & 3.95 & -1.072 & 0.299 & 2.411 & 0.235 \\
\hline \multicolumn{7}{|c|}{ Women } \\
\hline Clamidiosis & $45.80 \pm 34.15$ & 24.9 & - & - & - & - \\
\hline Trichomoniasis & $113.07 \pm 42.04$ & 33.45 & - & - & - & - \\
\hline Genital herpes & $8.26 \pm 4.75$ & 3.95 & - & - & - & - \\
\hline Anogenital warts & $15.29 \pm 9.63$ & 7.7 & - & - & - & - \\
\hline
\end{tabular}

Note: $\left(^{*}\right)$ - statistically significant difference $(\mathrm{p}<0,05)$.

Table 1: Parametric indicators of STI incidence among the population of the Novgorod region and Veliky Novgorod (indices per 100,000 population).

No gender differences in the rest of the diseases were observed. Assessing nonparametric data, the magnitude of the interquartile range for trichomoniasis was $\mathrm{M} \div \mathrm{M}=$ $160.22 \div 241.24$ with a maximum of 355.0 per 100,000 population in males.
The incidence rate among women is in the zone of the Gauss corridor and has significant differences from that of men. There is practically no difference in the Gaussian density.

\begin{tabular}{|c|c|c|c|c|c|}
\hline Indicators & $\mathbf{M}_{\text {med }}$ & M M & min & max & Gauss Density \\
\hline \multicolumn{5}{|c|}{ Movgorod region } \\
\hline \multicolumn{7}{|c|}{ Men } \\
\hline Clamidiosis & 59.7 & $29.59 \div 75.30$ & 20.65 & 98.2 & 77.55 \\
\hline Trichomoniasis & 198.05 & $160.22 \div 241.24$ & 115.97 & 355 & 239.03 \\
\hline Genital herpes & 4.33 & $2.82 \div 8.76$ & 2.17 & 12.97 & 10.8 \\
\hline Anogenital warts & 6.72 & $5.80 \div 9.25$ & 2.52 & 23.46 & 20.94 \\
\hline \multicolumn{5}{|c|}{ Women } \\
\hline Clamidiosis & 74.13 & $70.30 \div 92.80$ & 30.01 & 131.12 & 101.11 \\
\hline Trichomoniasis & 212.2 & $197.59 \div 300.30$ & 132.2 & 355.7 & 223.5 \\
\hline Genital herpes & 7.68 & $7.34 \div 8.91$ & 6.92 & 17.45 & 10.53 \\
\hline Anogenital warts & 10.38 & $7.60 \div 12.30$ & 4.75 & 19.5 & 14.75 \\
\hline \multicolumn{7}{|c|}{ Veliky Novgorod } \\
\hline \multicolumn{7}{|c|}{ Men } \\
\hline Clamidiosis & 81.64 & $23.90 \div 125.61$ & 21.5 & 229.52 & 208.02 \\
\hline Trichomoniasis & 407.2 & $358.30 \div 433.63$ & 173.95 & 520.6 & 346.65 \\
\hline Genital herpes & 8.48 & $4.14 \div 9.42$ & 3.15 & 23.06 & 19.91 \\
\hline Anogenital warts & 12.46 & $7.25 \div 13.95$ & 2.08 & 23.06 & 20.98 \\
\hline \multicolumn{7}{|c|}{ Women } \\
\hline Clamidiosis & 46.76 & $27.33 \div 50.57$ & 5.6 & 109.17 & 103.57 \\
\hline Trichomoniasis & 114.75 & $91.57 \div 144.48$ & 38.43 & 163.24 & 124.81 \\
\hline Genital herpes & 8.8 & $4.82 \div 11.95$ & 0.82 & 14.45 & 13.63 \\
\hline Anogenital warts & 13.66 & $4.92 \div 20.70$ & 4.76 & 31.05 & 26.29 \\
\hline
\end{tabular}

Table 2: Nonparametric indicators of STI incidence among the population of the Novgorod re-gion and Veliky Novgorod (indicators per 100,000 population). 


\section{Virology \& Immunology Journal}

Incidence of trichomoniasis in Veliky Novgorod is several times higher than in the Novgorod region and is equal to the interquartile range among men $\mathrm{M} \div \mathrm{M}=$ $358.30 \div 433.63$. For other diseases, there are no significant gender and territorial differences.

Ternary graph analysis with a constant incidence rate of HIV infection showed a sharp disruption of the dynamics in the structure of STIs, with the dominant indicator being the incidence rate among women, suggesting the effect of this indicator on the relationship with the incidence of HIV infection.

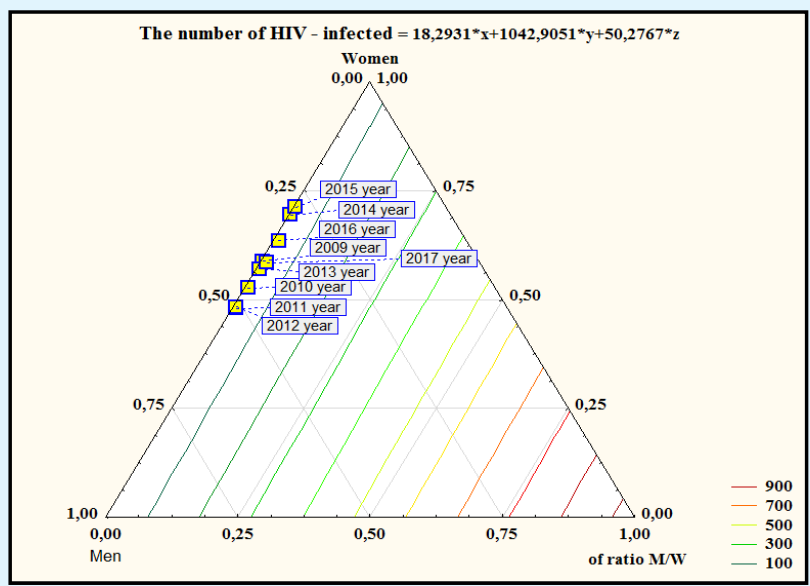

Figure 1: Characteristics of the mathematical dependence of the level of HIV infection on the incidence of chlamydia, taking into account the dynamics and sex among the population of the Novgorod region.

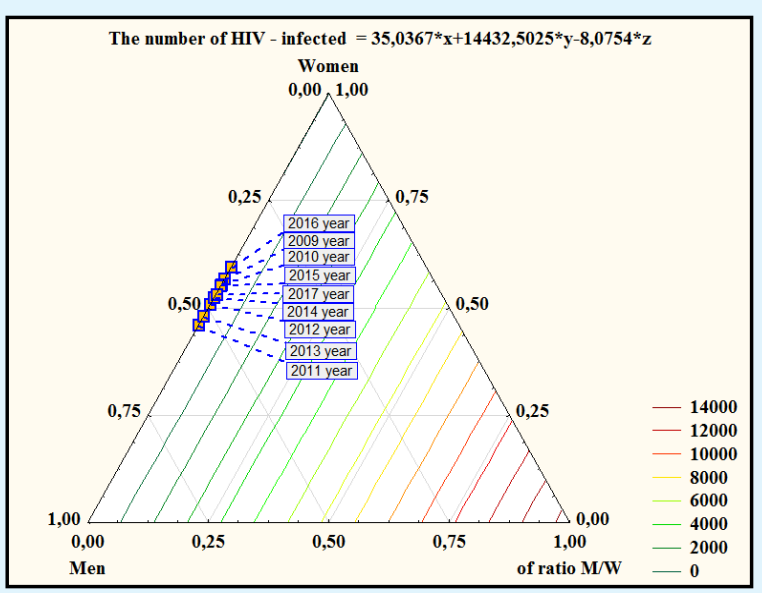

Figure 2: Characteristics of mathematical dependence of the level of HIV infection on the incidence of trichomoniasis, taking into account the dynamics and sex among the population of the Novgorod region.
This trend is most clearly seen when assessing the incidence of trichomoniasis, in the direct range determining the incidence of HIV infection.

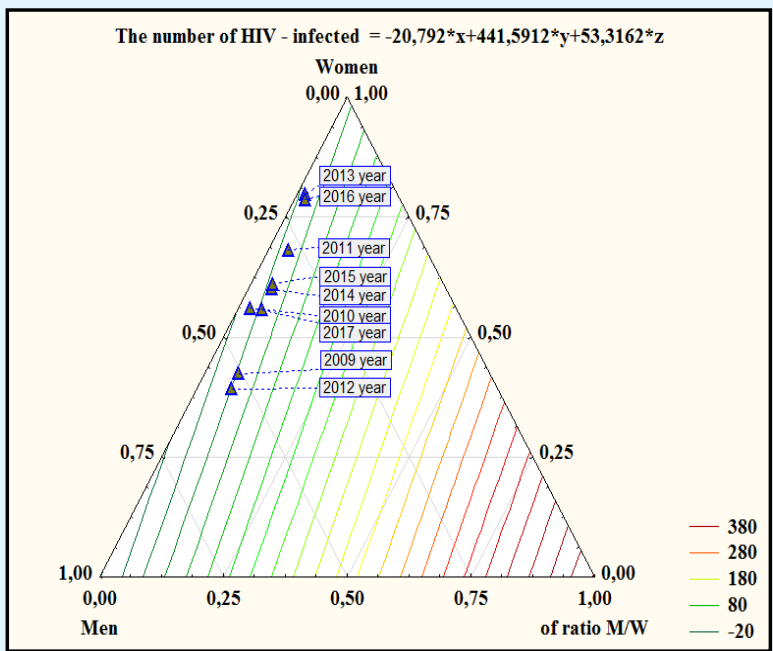

Figure 3: Characteristics of mathematical dependence of the level of HIV infection on the incidence of genital herpes, taking into account the dynamics and sex among the population of the Novgorod region.

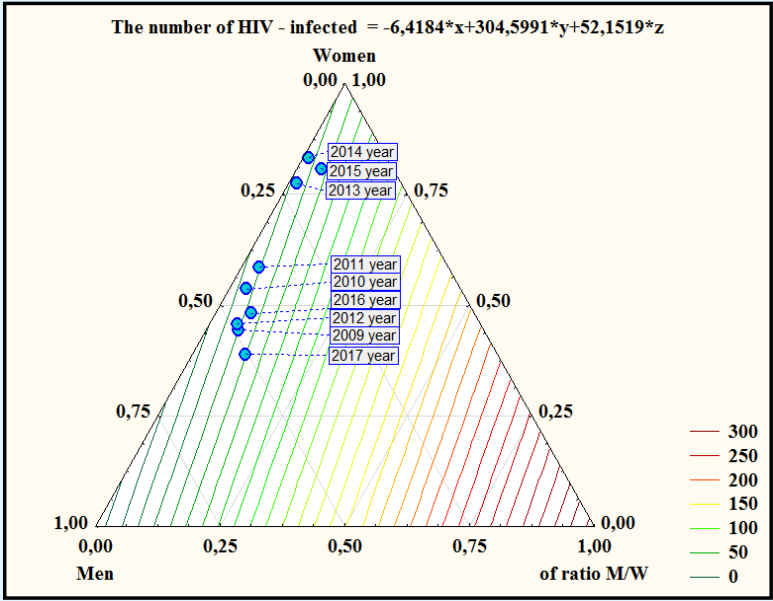

Figure 4: Characteristics of mathematical dependence of the level of HIV infection on the incidence of anogenital warts, taking into account the dynamics and sex among the population of the Novgorod region.

As shown on Figures 3 and 4, the incidences of genital herpes and anogenital warts have no specific features.

The incidence of chlamydia in Veliky Novgorod also does not have specific features (Fig. 5) and is 


\section{Virology \& Immunology Journal}

characterized by pronounced dynamics to a decrease in index and a tendency to higher inci-dence in men.

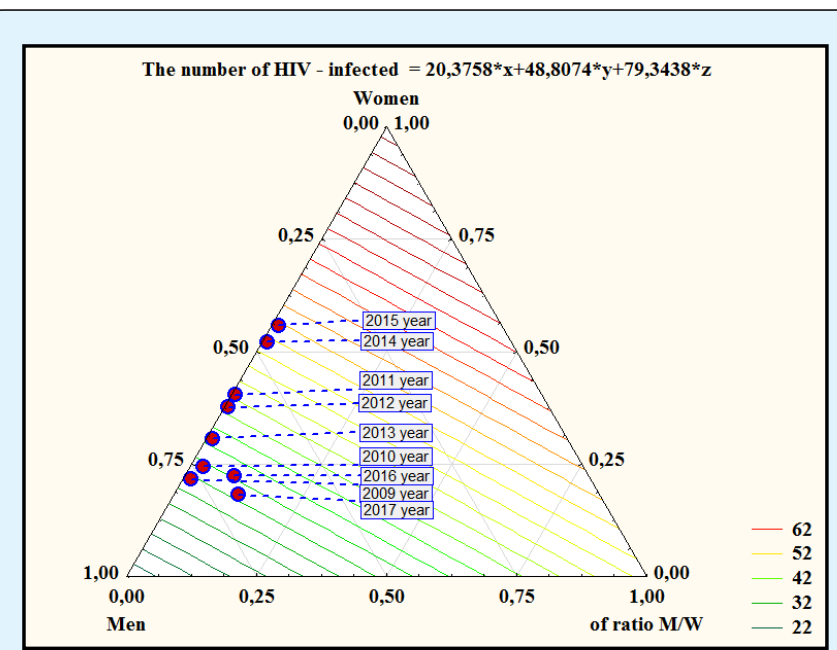

Figure 5: Characteristics of the mathematical dependence of the level of HIV infection on the incidence of chlamydia, taking into account the dynamics and sex among the population of the Veliky Novgorod.

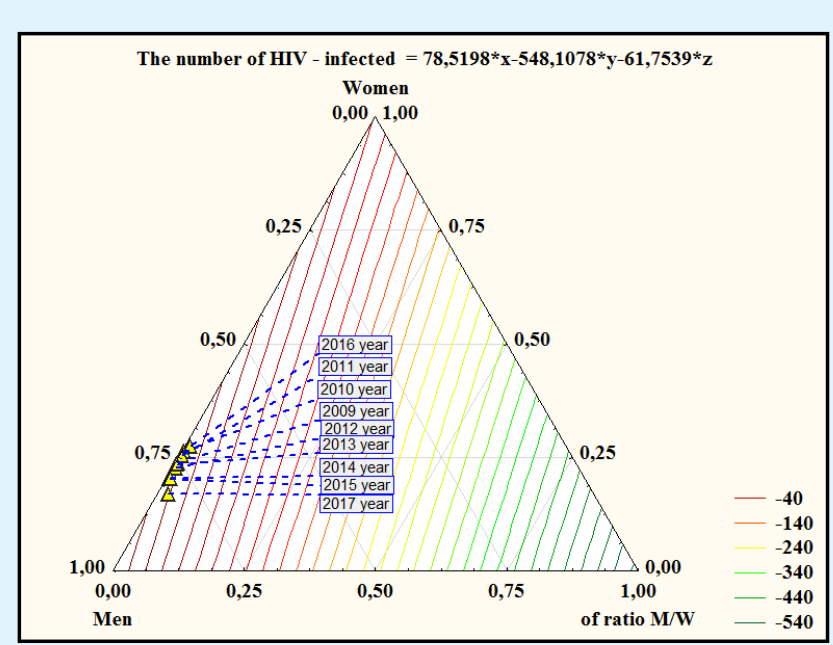

Figure 6: Characteristics of mathematical dependence of the level of HIV infection on the incidence of trichomoniasis, taking into account the dynamics and sex among the population of the Veliky Novgorod.

Unlike descriptive analysis, ternary dependence indicates a prevalence of trichomoniasis among women which has an impulsive dynamic character. The highest incidence was recorded in 2011 and 2016. At the same time, the incidence of HIV infection in Veliky Novgorod was lower than in the whole region.

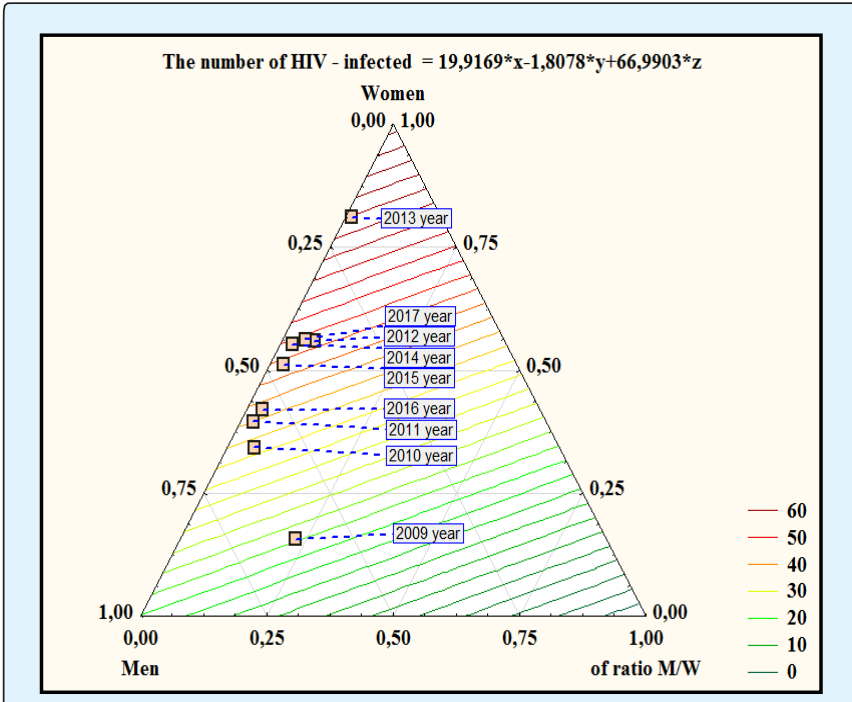

Figure 7: Characteristics of mathematical dependence of the level of HIV infection depending on the incidence of genital herpes, taking into account the dynamics and sex among the population of the Veliky Novgorod.

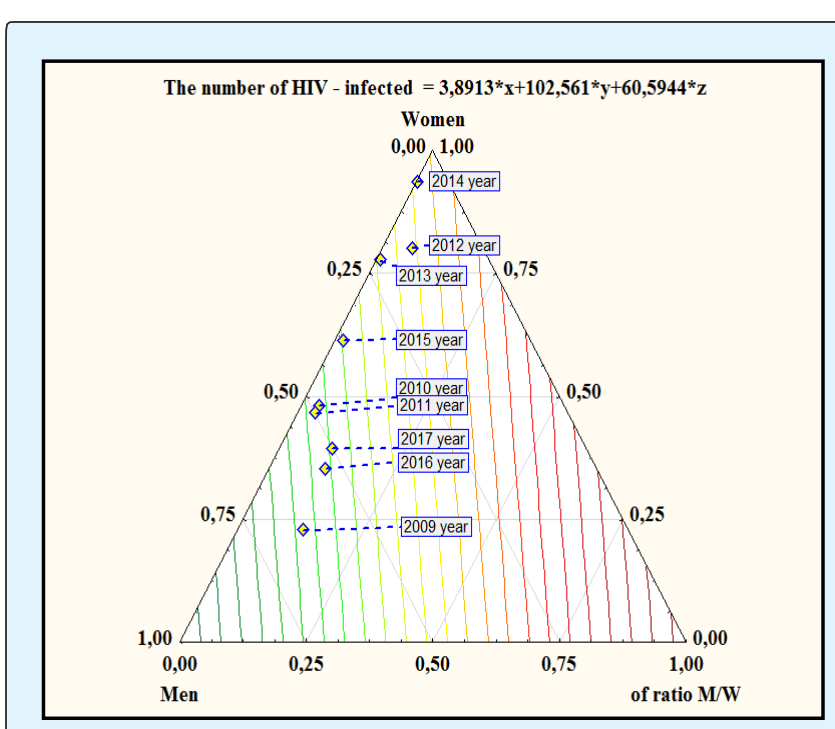

Figure 8: Characteristics of mathematical dependence of the level of HIV infection depending on the incidence of anogenital warts, taking into account the dynamics and sex among the population of the Veliky Novgorod.

As can be seen in Figures 7 and 8, incidence of genital herpes and genital warts also does not have specific features. 


\section{Virology \& Immunology Journal}

\begin{tabular}{|c|c|c|c|}
\hline Chlamydia & Trichomoniasis & Genital herpes & Anogenital warts \\
\hline \multicolumn{4}{|c|}{ Novgorod region } \\
\hline $18,3{ }_{\mathrm{x}}+1042,9{ }_{\mathrm{y}}+50,3{ }_{\mathrm{z}}$ & $35,0{ }_{x}^{*}+14432,5^{*}{ }_{y}-8,1^{*}{ }_{z}$ & $-20,8^{*}{ }_{x}+441,6_{y}^{*}+33,3^{*}$ & $-6,4^{*}{ }_{\mathrm{x}}+304,6{ }_{\mathrm{y}}+52,1_{\mathrm{z}}{ }_{\mathrm{z}}$ \\
\hline \multicolumn{4}{|c|}{ Veliky Novgorod } \\
\hline $20,4{ }_{x}^{*}+48,8{ }_{y}+79,3{ }^{*}$ & $78,{ }^{*}{ }_{\mathrm{x}}-548,1{ }_{\mathrm{y}}-61,7_{\mathrm{z}}$ & $19,9 *_{x}-1,8{ }^{*}+66,9 *_{z}$ & $3,8^{*}+102,5^{*}{ }_{y}+60,6^{*}{ }_{z}$ \\
\hline
\end{tabular}

Table 3: Summary data of mathematical dependence of HIV incidence among the population of the Novgorod region and Veliky Novgorod depending on the level of morbidity of the population taking into account sex on and a number of STIs (ternary analysis).

Thus, as can be seen from Table 3, it is clear that trichomoniasis is the dominant disease that determines the incidence of HIV infection. Recalculations of the model for absolute figures will allow to determine the true level of the incidence of HIV infection already at the preclinical stage.

\section{Summary}

1. Sexually transmitted infections are risk factors for HIV infection.

2. Among all STIs studied by us, trichomoniasis is predominant to female subpopulation.

3. In the risk groups, different sex networks cross the STI pathogens, which leads to a significant number of cases of infection by multiple pathogens in one person.

4. The possibility of combined infection indicates the need for clinicians for detailed diagnosis in case of suspected STI and complete cure of patients, given the role of these infections in the spread of HIV infection.

5 . With the manifestation of STIs detected, tertiary analysis of STI incidence is implementable for calculating the possible number of HIV-infected patients in the regions at the preclinical stage.

\section{References}

1. Pokrovskij VV (2004) VICh-infekcija: prognoz. Voprosy virusologii 3: 31-4.

2. Tapsall JW, Kinchington M (1996) The frequency of co-infection with Neisseria gonorrhoeae and Chlamydia trachomatis in men and women in eastern Sydney. Pathology 28(1): 84-87.

3. Tursunov R (2013) Znachenie polovogo puti peredachi v razvitii epidemii VICH- infekcii. Medicina 3: 46-55.

4. WHO/UNAIDS (2011) Sexually transmitted diseases: policies and principles for prevention and care.
5. World Health Organization (2008) Global incidence and prevalence of selected curable sexually transmitted infections.

6. Grechanskaja LV (2006) Klinikojepidemiologicheskaja harakteristika i lechenie infekcij, peredajushhihsja polovym putjom, u VIChinficirovannyh: Avtoref dis kand med nauk Har'kov 23.

7. Plavinskii S, Barinova A, Eroshina K, Bobrik A, Novogilov A (2013) Infekcii . peredavaemii polovim putem i Vich-infekciia $\mathrm{V}$ grupach riska. Rasprostraniautsia li vozbuditeli po odnim I te ge setiam? Medicina 3: 46-56.

8. CDC (2007) Update to CDC's Sexually Transmitted Diseases Treatment Guidelines, 2006: Fluoroquinolones No Longer Recommended for Treatment of Gonococcal Infections. Morbid Mortal Wkly Rep 56(14): 332-336.

9. Pokrovskij VV (2004) Social'no znachimye infekcii v XXI veke. Nar-odonaselenie. 3: 93-96.

10. Satterwhite CL, Torrone E, Meites E, Dunne EF, Mahajan R, et al. (2013) Sexually transmitted infections among U.S. women and men: Prevalence and incidence estimates, 2008. Sex Transm Dis 40(3): 187-193.

11. Sharp PM, Hahn BH (2011) Origins of HIV and the AIDS pandemic. Cold Spring Harb Perspect Med 1(1): a006841.

12. Poynten IM, Templeton DJ, Grulich AE (2011) Sexually transmissible infections in aging HIV populations. Sex Health 8(4): 508-511.

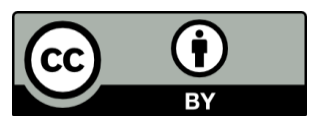

